\title{
KETERBACAAN VISUAL MEDIA BUKU CERITA FABEL “KURA-KURA SANG JUARA"
}

\author{
Silvi Luftiah Hasanah ${ }^{1}$, Atin Fatimah ${ }^{1}$, Kristiana Maryani ${ }^{1}$ \\ ${ }^{1}$ Pendidikan Guru Anak Usia Dini, Fakultas Keguruan Dan Ilmu Kependidikan, Universitas Sultan \\ Ageng Tirtayasa, Jl. Ciwaru Raya No.25, Cipare, Kec. Serang, Kota Serang, Banten 42117
}

Penulis untuk Korespondensi/ Email: Silviluftiahhasanah@gmail.com

\begin{abstract}
Abstrak - Keterbacaan Visual merupakan kemampuan untuk menterjemahkan dan menginterpretasikan gambar/visual yang terdapat dalam sebuah informasi. Kemampuan ini perlu dikuasai oleh anak agar anak dapat membaca isi dari sebuah informasi dengan baik tanpa salah persepsi. Tujuan penelitian ini untuk mendapakan informasi tentang Keterbacaan Visual Media Buku Cerita Fabel "Kura-Kura Sang Juara" Anak Usia 5-6 Tahun di Cluster Rakata Green Hill Kelurahan Ciwedus Kecamatan Cilegon Kota Cilegon-Banten. Penelitian ini menggunakan metode penelitian kualitatif deskriptif. Prosedur pengumpulan data yang digunakan dalam penelitian ini adalah observasi, wawancara, dokumentasi, catatan lapangan dan validasi uji ahli. Analisis data menggunakan reduksi data, penyajian data, dan penarikan kesimpulan. Berdasarkan hasil penelitian disimpulkan bahwa bahwa keterbacaan visual media buku cerita fabel "Kura-Kura Sang Juara" anak usia 5 - 6 tahun di Cluster Rakata Green Hil adalah baik karena telihat dari ketika anak membaca buku cerita fabel "Kura-Kura Sang Juara" dengan baik, anak dapat menjawab pertanyaan mengenai buku cerita fabel "Kura-Kura Sang Juara" serta dapat meceritakan kembali kepada peneliti atau orang tuanya tentang isi dari buku cerita fabel "Kura-Kura Sang Juara".
\end{abstract}

Kata Kunci - keterbacaan visual, media buku cerita, anak usia 5-6 tahun.

Abstract - Visual literacy is the ability to translate and interpret images/visuals contained in an information. This ability needs to be mastered by the child so that the child can read the content of information well without misperception. The purpose of this study is to obtain information about Visual literacy media Fable Storybook "Turtles The Champion" Children Aged 5-6 Years in Cluster Rakata Green Hill Ciwedus Subdistrict Cilegon Cilegon-Banten. This research uses descriptive qualitative research methods. The data collection procedures used in this study are observation, interview, documentation, field notes and expert test validation. Data analysis uses data reduction, data presentation, and conclusion drawing. Based on the results of the study concluded that the visual readability of the fable storybook "Turtle the Champion" children aged 5 - 6 years in The Rakata Green Hil Cluster is good because it can be seen from when the child reads the fable story book "Turtle the Champion" well, the child can answer questions about the fable story book "Turtle the Champion" and can tell back to the researcher or his parents about the contents of the fable story book "Turtle the Champion".

Keywords - visual literacy, storybook media, children aged 5-6 years 


\section{PENDAHULUAN}

$\mathrm{B}$ uku adalah salah satu dari banyak media yang sering di pakai oleh seorang guru untuk menyampaikan sebuah pesan pembelajaran. Buku sudah ada sejak zaman kuno namun dengan bahan media penulisan yang berbeda. Buku yang lahir pada zaman kuno berisikan informasi, do'a-do'a, syair, kisah, adat dan kebiasaan yang akan di wariskan kepada generasinya yang sebelumnya disampaikan lewat lisan. Melalui buku pewarisan berbagai tradisi, ajaran, kisah, nilai-nilai, kepercayaan, praktik ritual, dan sebagainya menjadi lebih mudah.

Keterbacaan visual memberikan anak sebuah kemampuan untuk dapat membaca dan mengungkapkan informasi sebuah gambar yang anak temukan dan kemudian dapat mempresentasikan kembali dengan cara yang berbeda. Untuk membangun kemampuan ini, membacakan atau memberikan buku cerita bergambar adalah salah satu cara yang dapat dilakukan oleh seorang pengajar di sekolah maupun oleh orang tua di rumah.

Mengajarkan keterbacaan visual pada anak prasekolah adalah salah satu cara agar anak dapat memiliki kemahiran dalam menganalisis sebuah gambar yang terlihat dilingkungan sekitar, terlebih pada anak prasekolah masih banyak anak yang belum mahir membaca.

Berdasarkan latar belakang permasalahan di atas, maka peneliti merumuskan judul penelitian "Keterbacaan Visual Media Buku Cerita Fabel 'Kura-Kura Sang Juara' Anak Usia 5 - 6 Tahun di Cluster Rakata Green Hill Kelurahan Ciwedus Kecamatan Cilegon Kota Cilegon-Banten"

Tujuan penelitian ini adalah untuk mendapatkan informasi tentang Keterbacaan Visual Media Buku Cerita Fabel "Kura-Kura Sang Juara" Anak Usia 56 Tahun di Cluster Rakata Green Hill Kelurahan Ciwedus Kecamatan Cilegon Kota Cilegon-Banten.

Manfaat dari penelitian ini yaitu dapat menambah wawasan dan pengalaman secara langsung tentang keterbacaan visual media buku cerita anak udia 5-6 tahun, dapat memberikan inovasi dalam pengembangan media pembelajaran sehingga dapat menghasilkan kegiatan pembelajaran yang menyenangkan, dan untuk anak dapat memberikan kegiatan bermain dan belajaran yang menyenangkan melalui membaca buku cerita atau mendengarkan cerita sehingga isi pembelajaran dapat terus melekat pada ingatan anak.

Debes mendefinisikan keterbacaan visual sebagai "a set of competences owned by a person to discriminate and interpret the visible actions, objects and symbols, natural or man-made, that he encounters in his environment, and to apply the competences to communicate with others and to appreciate visual text" (Arizpe \& Styles, 2015: 124). Pernyataan tersebut memiliki arti bahwa seperangkat kompetensi yang dimiliki oleh seseorang untuk membedakan dan menafsirkan tindakan yang terlihat, objek dan simbol, alami atau buatan manusia, yang dia temui di lingkungannya, dan menerapkan kompetensi untuk berkomunikasi dengan orang lain dan untuk memahami teks visual.

Pendapat lain juga disampaikan oleh Riddle (2009: 3) bahwa keterbacaan visual adalah kemampuan untuk menafsirkan, menggunakan, dan menciptakan media visual untuk meningkatkan proses, pengambilan keputusan, komunikasi, dan pembelajaran. Media visual memiliki peranan sangat penting dalam penyampaian pesan dalam proses pembelajaran. Pesan tersebuat dituangkan kedalam sebuah simbol, gambar, objek dan lainnya yang dapat dilihat oleh indera penglihatan.

Dari beberapa pendapat di atas dapat disimpulkan bahwa keterbacaan visual (Visual Literacy) adalah kemampuan dalam membaca, membedakan, menafsirkan, dan menyampaikan sebuah informasi dalam bentuk visual baik berupa gambar, ilustrasi maupun teks selanjutnya pemahaman tersebut digunakan dalam berkomunikasi dengan lingkungannya.

Buku merupakan sumber ilmu bagi manusia, banyak informasi yang terdapat didalamnya. Buku menjadi salah satu media yang sering digunakan oleh guru untuk menyampaikan pesan dalam pembelajaran. Pada siswa usia pra sekolah buku cerita biasanya paling sering digunakan untuk menyampaikan sebuah informasi dalam pembelajaran.

Menurut Mitchell (2003:87), "Picture storybooks are books in which the picture and text are tightly intertwined. Neither the pictures nor the words are selfsufficient; they need each other to tell the story" pernyataan tersebut memiliki arti buku cerita bergambar adalah buku yang didalamnya memiliki gambar dan teks yang berkaitan erat. Baik gambar atau pun teks tidak mencukupi; mereka saling bergantung menjadi sebuah cerita. 
Rothlein dan Meinbach dalam Adipta dkk (2016: 989) "a picture storybooks conveys its message through illustrations and written text; both elements are equally important to the story". Pendapat tersebut memiliki arti bahwa buku cerita bergambar adalah buku yang menyampaikan pesan melalui ilustrasi yang berupa gambar dan tulisan. Gambar dan tulisan tersebut membentuk kesatuan yang utuh.

Sedangkan menurut Nurgiyantoro (2005: 125) buku cerita bergambar adalah buku bacaan cerita yang menampilkan teks narasi secara verbal dan disertai gambar-gambar ilustrasi. Gambar ilustrasi ini dibuat untuk memberikan bayangan pada setiap karakter yang ada pada cerita tersebut sehingga ketika pembaca bisa bermain imajinasi dengan gambar tersebut.

Berdasarkan pendapat di atas mengenai buku cerita bergambar dapat ditarik kesimpulan bahwa buku cerita bergambar adalah buku yang didalamnya memiliki sebuah alur cerita yang diilustrasikan dalam bentuk gambar dan teks yang keduanya saling berkaitan. Gambar ilustrasi membantu pembaca untuk memahami isi buku cerita tersebut.

Siswa usia prasekolah memiliki kemampuan yang berbeda-beda dalam kemampuan berbahasa (mendengar, berbicara, membaca, dan menulis). Menurut Suyanto (2005: 169) menyatakan bahwa siswa usia 5-6 tahun berada pada peralihan tahap perkembangan kemampuan membaca lanjut dan mandiri. Sehingga untuk siswa usia tersebut sebaiknya disediakan buku bergambar yang berwarna-warni dengan ukuran huruf yang relatif besar agar siswa tertarik untuk membaca.

Sedangkan menurut Menurut Sutherland dalam Faizah (2009:252) karakteristik buku cerita adalah sebagai berikut: (1) Buku cerita bersifat ringkas dan langsung, (2) buku cerita bergambar berisi konsepkonsep yang berseri, (3) konsep yang ditulis dapat dipahami oleh anak-anak, (4) gaya penulisanya sederhana, (5) terdapat ilustrasi yang melengkapi teks. Buku cerita untuk siswa usia dini hendaknya memiliki cerita yang ringkas dengan penulisan yang sederhana. Buku cerita yang tebal dan alur cerita yang panjang akan dengan mudah membuat anak merasa bosan membacanya dan memungkinkan anak sulit untuk mencerta alur dari cerita tersebut.

Berdasarkan pendapat di atas, dapat ditarik kesimpulan bahwa karakteristik buku yang tepat untuk siswa usia 5-6 tahun yaitu buku bergambar harus memiliki tampilan visual menarik dengan pemilihan warna dan ilustrasi yang baik. Dengan adanya ilustrasi siswa usia dini akan lebih mudah memahami jalan cerita sebuah buku sekaligus dapat melatih imajiasi siswa melalui gambar ilustrasi tersebut. Bukan hanya gambar yang baik penggunaan bahasa yang ringan dengan kosa kata sederhana dapat mempermudah cerita dicerna oleh siswa.

\section{METODE PENELITIAN}

Menurut Moleong (2010: 6), penelitian kualitatif adalah penelitian yang bermaksud untuk memahami fenomena tentang apa yang dialami oleh subjek penelitian misalnya perilaku, persepsi, motivasi, tindakan dan lain sebagainya. Secara holistik dan dengan cara deskripsi dalam bentuk kata-kata dan bahasa, pada suatu konteks khusus yang alamiah dan dengan memanfaatkan berbagai metode alamiah.

Dalam penelitian ini, peneliti menggunakan metode kualitatif dengan alasan bahwa peneliti ingin mengumpulkan, memperoleh dan menyimpulkan data yang didapat secara alamiah sesuai dengan fakta kejadian di lapangan tanpa diatur melalui test atau eksperimen. Peneliti ingin mengetahui dan mendeskripsikan bagaimana kualitas keterbacaan visual buku cerita fabel yang berjudul "Kura-Kura Sang Juara" dari mulai penggunaan kosa kata, kualitas gambar, hingga kesesuian gambar dengan kosa kata yang digunakan penulis.

Penelitian ini dilaksanakan di Cluster Rakata Green Hill Kelurahan Ciwedus Kecamatan Cilegon Kota Cilegon-Banten. Penelitian ini dilakukan pada bulan Desember 2020.

Sumber data dalam penelitian ini adalah anak dan orang tua yang disebut informan. Dalam penelitian ini pengumpulan data dilakukan dalam kondisi alamiah maka dengan teknik pengumpulan data sebagai berikut: (a) Observasi, Alasan peneliti melakukan observasi adalah untuk mendapatkan data dan informasi tentang anak sebagai subjek penelitian. Dimana hasil observasi dituangkan dalam catatan lapangan.(b) Wawancara, untuk mendapatkan sebuah informasi peneliti akan melakukan tanya jawab dengan anak dan orang tua yang merupakan narasumber dalam penelitian. Peneliti menggunakan selembaran pertanyaan tentang kualitas keterbacaan visual buku cerita fabel "Kura-Kura Sang Juara" kepada narasumber yang mendukung penelitian. (c) Dokumentasi, digunakan untuk memperkuat data yang diperoleh dari hasil observasi dan wawancara. Dokumentasi dilakukan untuk memberikan gambaran secara visual 
mengenai kegiatan anak berupa foto-foto atau video serta rekaman yang diambil selama penelitian. Dokumentasi dilakukan untuk pembuktian bahwa penelitian yang dilakukan benar adanya. (d) Catatan lapangan, peneliti metulis tentang apa yang didengar, dilihat, dialami, dan dipikirkan dalam rangka pengumpulan data dan refleksi terhadap data dalam penelitian kualitatif. (e) Validasi uji ahli, untuk mencapai hasil penelitian yang mendalam dan akurat, peneliti melakukan validasi uji ahli materi. Validasi uji materi dilakukan dengan meminta seseorang yang ahli dalam bidang bahasa yaitu Dr. Ade Husnul Mawadah, S.S., M. Hum. untuk melakukan penilaian pada buku "Kura-Kura Sang Juara" yang akan digunakan dalam penelitian, apakah buku ini sudah sesuai dengan instrumen yang didesain peneliti.

Sugiyono (2010: 335) analisis data adalah proses mencari dan menyusun secara sistematis data yang diperoleh dari hasil wawancara, observasi, catatan lapangan, dan dokumentasi, dengan cara mengorganisasikan data ke dalam kategori, menjabarkan ke dalam unit-unit, melakukan sintesa, menyusun ke dalam pola, memilih mana yang penting dan yang akan dipelajari dan membuat kesimpulan sehingga mudah difahami oleh diri sendiri maupun orang lain. Analisis data dalam penelitian ini menggunakan teknik Miles dan Huberman. Miles dan Huberman dalam Sugiyono (2014: 243) mengatakan bahwa analisis terdiri dari tiga alur kegiatan yang terjadi secara bersamaan yaitu reduksi data, penyajian data, dan penarikan kesimpulan/verification.

akurat, peneliti melakukan validasi uji ahli materi. Validasi uji materi dilakukan dengan meminta seseorang yang ahli dalam bidang bahasa yaitu Dr. Ade Husnul Mawadah, S.S., M. Hum. untuk melakukan penilaian pada buku "Kura-Kura Sang Juara" yang akan digunakan dalam penelitian, apakah buku ini sudah sesuai dengan instrumen yang didesain peneliti.

Sugiyono (2010: 335) analisis data adalah proses mencari dan menyusun secara sistematis data yang diperoleh dari hasil wawancara, observasi, catatan lapangan, dan dokumentasi, dengan cara mengorganisasikan data ke dalam kategori, menjabarkan ke dalam unit-unit, melakukan sintesa, menyusun ke dalam pola, memilih mana yang penting dan yang akan dipelajari dan membuat kesimpulan sehingga mudah difahami oleh diri sendiri maupun orang lain. Analisis data dalam penelitian ini menggunakan teknik Miles dan Huberman. Miles dan Huberman dalam Sugiyono
(2014: 243) mengatakan bahwa analisis terdiri dari tiga alur kegiatan yang terjadi secara bersamaan yaitu reduksi data, penyajian data, dan penarikan kesimpulan/verification.

\section{HASIL DAN PEMBAHASAN}

Penelitian ini dilakukan di Cluster Rakata Green Hill merupakan salah satu Cluster baru yang ada di Perumahan Bumi Rakata Asri Kelurahan Ciwedus Kecamatan Cilegon Kota Cilegon Banten. Menurut ketua RT Cluster Rakata Green Hill, penduduk yang tinggal atau sudah berdomisili di Cluster Rakata Green Hill ini sebanyak 56 Kepala Keluarga dan sebagian besar penduduk Cluster Rakata Green Hill bekerja sebagai karyawan di pabrik industri. Anak usia dini 5-6 tahun di Cluster Rakata Green Hill ini sebanyak 5 orang anak namun peneliti mengambil sampel 3 orang anak usia 5-6 tahun.

Buku Cerita Fabel "Kura-kura Sang Juara" terdiri dari (1) Bagian sampul, yaitu sampul depan dan belakang. Pada sampul bagian depan buku cerita terdiri dari judul, keterangan tema cerita, dan keterangan bahasa yang digunakan. (2) Isi Buku, berisikan bagaimana Kura-kura ditantang untuk lomba lari oleh Kelinci. Namun Kelinci kalah karena kesombongannya. Isi Cerita disajikan dalam dua bahasa yaitu Bahasa Indonesia dan Bahasa Inggris dengan Gambar yang mendukung Cerita.

Data mengenai keterbacaan visual media buku cerita fabel "kura-kura sang juara" anak usia 5-6 tahun diperoleh berdasarkan wawancara, catatan lapangan dan dokumentasi. Sebagaimana indikator keterbacaan visual media buku cerita bergambar adalah sebagai berikut: pengguaan bahasa singkat, keamanan media, keawetan media, kemudahan penggunaan media, ketepatan media dengan cerita, kesesuaian gambar dengan cerita, ketepatan komposisi warna, buku cerita bersifat ringkas dan langsung, buku cerita bergambar berisi konsepkonsep yang berseri, konsep yang ditulis dapat dipahami oleh anak, gaya penulisan sederhana, terdapat ilustrasi yang melengkapi teks.

Buku cerita fabel "kura-kura sang juara" merupakan buku cerita yang mudah digunakan oleh anak terlihat ketika melakukan penelitian bahwa anak dapat membaca buku cerita fabel "kura-kura sang juara" (CL02, CL06, CL09). Hal ini selaras dengan hasil wawancara dengan anak yang menyatakan bahwa "aku bisa baca buku sendiri, mudah dibaca sendiri" (CWA01), "bisa" (CWA02), "bisa" (CWA03). Selain mudah di pahami buku cerita fabel "kura-kura sang juara" memiliki bahan yang 
awet dan aman dalam penggunaannya (CL01, CL04, CL07). Hal ini sejalan dengan jawaban wawancara orang tua murid bahwa "Bahannya awet", "bukunya aman buat anak-anak" (CWO01), "Bahannya awet sih sebenernya, gimana anaknya", "Bukunya aman sih" (CWO02), " bahannya awet, kan agak licin kalau kotor bisa di hapus", "Bukunya aman" (CWO03).

Buku cerita fabel "kura-kura sang juara" menggunakan bahasa yang singkat dan tulisan yang jelas, cerita yang bersifat ringkas dan langsung. Terlihat pada gambar 4.5 bahwa dalam cerita tidak terdapat pendahuluan cerita yang panjang, melainkan langsung memperkenalkan watak tokoh kelinci. Sehingga ketika anak-anak membaca buku ini akan menyukainya dan tidak merasa bosan dengan alur ceritanya.

Dengan keterbacaan tulisan yang jelas akan mempermudah anak-anak untuk membaca dan memahami isi cerita yang terdapat dalam buku tersebut. Hal ini terlihat ketika melakukan tanya jawab dengan anak mengenai isi buku cerita fabel "kura-kura sang juara" bahwa anak dapat menyebutkan setiap tokoh dan menceritakan kembali isi dari buku cerita fabel "kura-kura sang juara" (CL01, CL05, CL08) (CD02, CD04, CD06). Hal ini sesuai dengan hasil wawancara dengan anak "aku bisa, ada kura-kura lomba lari sama kelinci trus yang kalah kelinci soalnya tidur di bawah pohon" (CWA01), "Udah paham ceritanya, kura kura sama kelinci lomba lari. Kura - kura menang kelinci kalah karna tidur dibawah pohon. Kelincinya sombong jadi kalah" (CWA02), “ Paham, si kelinci ngajak kura-kura lomba lari tapi kelinci sombong saat lomba kelinci tidur dan kurakura menang" (CWA03).

Selain menggunakan tulisan pada buku cerita fabel "kura-kura sang juara" dilengkapi dengan gambargambar dengan komposisi warna dan kejelasan gambar yang baik disesuaikan dengan aslinya di dunia nyata sehingga menarik anak-anak untuk membaca serta anak dapat mengetahui tokoh apa saja yang ada dalam buku cerita tersebut (CL01, CL05, CL08) (CD02, CD04, CD06). Hal ini berdasarkan hasil wawancara dengan anak "ada gambar kelinci, kura-kura, dan singa" (CWA01), “ kelinci, kura-kura, sama singa" (CWA02), "gambar kelinci, kura-kura, san singa" (CWA03), "perpaduan warnanya menarik, nyata" (CWO01), "bukunya warnanya bagus sesuai dengan anak anak" (CWO02), "gambar komposisi warnanya udah cukup menarik buat anak - anak perhatikan gambarnya" (CWO03).
Dengan adanya ilustrasi yang dilengkapi text, buku cerita fabel "kura-kura" sang juara ini juga memiliki kesesuian antara gambar dengan cerita yang disampaikan (CL01, CL04, CL07), "bukunya gambarnya setiap halaman nyambung" (CWO01), "cerita dan gambar sesuai" CWO02, "gambarnya sama ceritanya sudah cukup tepat" CWO03. Seperti gambar berikut yang menjelaskan bahwa kelinci sedang duduk di bawah pohon dan sedang bernyanyi. Maka pada gambar 4.6 kondisi tersebut diilutrasikan dengan gambar kelinci yang sedang duduk dibawah pohon, sehingga anak-anak dengan mudah mengetahui kondisi yang sedang terjadi secara nyata.

Berdasarkan hasil dari pengamatan, wawancara dan dokumentasi menunjukkan bahwa buku cerita fabel "kura-kura sang juara" anak usia 5-6 tahun dapat digunakan untuk anak-anak di usia 5-6 tahun dan memiliki keterbacaan visual yang baik. Hal ini dapat dilihat dalam catatan lapangan (CL01, CL02, CL03, CLO4, CL05, CL06, CLO7, CL08, CL09, CL10, CL11, dan CL12), hasil wawancara (CWO01, CWO02, CWO03, CWA01, CWA02, CWA03), dan catatan dokumentasi (CD01, CD02, CD03, CD04, CD05, CD06).

Berdasarkan pemaparan di atas dapat disimpulkan bahwa buku cerita kura-kura sang juara memiliki media kekesuaian gambar dengan cerita yang baik dan anak-anak mudah memahami cerita. Sehingga dapat dikatakan bahwa buku cerita kura-kura sang juara memiliki keterbacaan visual yang baik.

Di dalam penelitian ini dilaksanakan validasi oleh ahli materi. Validasi uji materi dilakukan oleh ahli dalam bidang bahasa yaitu Dr. Ade Husnul Mawadah, S.S., M. Hum. Menurut ahli buku cerita Kura-kura Sang Juara merupakan buku cerita yang telah memenuhi indikator-indikator berikut ini : mudah dipahami oleh anak, penggunaan bahasa yang singkat, keterbacaan tulisan yang baik, kejelasan gambar, kemanan media, keawetan media, kemudahan penggunaan media, ketepatan media dengan cerita, kesesuaian gambar dengan cerita, ketepatan komposisi warna, buku cerita bersifat ringkas dan langsung, konsep yang ditulis dalam cerita dapat dipahami oleh anak, gaya penulisan sederhana, terdapat ilustrasi yang dilengkapi dengan teks, dan buku cerita ini bukanlah buku cerita bergambar yang berisi konsep-konsep yang berseri. Sehingga dapat disimpulkan bahwa buku cerita Kura-kura Sang Juara sudah sesuai dan dapat digunakan sebagai media visual. 
Menurut Mitchell (2003:87), "Picture storybooks are books in which the picture and text are tightly intertwined. Neither the pictures nor the words are selfsufficient; they need each other to tell the story". Dengan kata lain, buku cerita bergambar adalah buku yang didalamnya memiliki gambar dan teks yang berkaitan erat. Sejalan dengan hasil penelitian keterbacaan visual media buku cerita fabel "KuraKura Sang Juara" anak usia 5-6 tahun, berdasarkan hasil wawancara dengan orang tua murid di Cluster Rakata Green Hill menyatakan bahwa gambar pada buku cerita kura-kura sang juara sudah sesuai dengan cerita.

Sutherland dalam Umi Faizah (2009:252) menyatakan bahwa karakteristik buku cerita yaitu: (1) Buku cerita bersifat ringkas dan langsung, (2) gaya penulisanya sederhana. Hal ini sejalan dengan hasil wawancara dengan orang tua murid di Cluster Rakata Green Hill menyatakan bahwa buku cerita kura-kura sang juara merupakan buku cerita yang ringkas dan langsung dengan gaya penulisan yang sederhana.

Ilustrasi pada buku cerita bergambar bukan hanya sebagai pelengkap pada tulisan saja, tetapi juga sebagai media komunikasi visual yang dapat membantu anak untuk merangsang imajinasi agar membayangkan alur cerita yang lebih mendalam lagi. Dengan ilustrasi gambar tokoh - tokoh cerita yang menarik, ketepatan komposisi warna yang bagus dapat membuat anak - anak tertarik untuk membaca dan memahami alur cerita. Menurut Nurgiyanto (2005:210), menyatakan bahwa buku yang tepat untuk siswa seharusnya memenuhi persyaratan berikut: (a) materi dapat dipahami siswa, (b) menggunakan bahasa yang sederhana sehingga dapat dibaca dan dipahami siswa, (c) mempertimbangkan kesederhanaan (kompleksitas) kosakata dan struktur, (d) berfungsi meningkatkan kekayaan bahasa dan kemampuan berbahasa siswa. Penyataan ini senada dengan hasil wawancara peneliti dengan orang tua murid dan hasil wawancara dengan anak menyatakan bahwa buku cerita kura-kura sang juara mudah untuk dipahami.

Buku cerita yang tidak berseri dapat mengurangi rasa bosan pada anak saat membaca cerita dan anak dapat langsung mengambil kesimpulan terhadap cerita tersebut. Menurut Sutherland dalam Faizah (2009:252) menyatakan bahwa buku cerita yang tebal dan alur cerita panjang akan membuat anak mudah merasa bosan membacanya dan memungkinkan anak sulit untuk memahami alur cerita tersebut. Pernyataan ini senada dengan hasil wawancara peneliti bahwa buku cerita kura-kura sang juara merupakan buku cerita yang tidak berseri.

Menurut Nurgiyantoro (2005: 125) buku cerita bergambar adalah buku bacaan cerita yang menampilkan teks narasi secara verbal dan disertai gambar-gambar ilustrasi. Pernyataan ini senada dengan hasil wawancara peneliti bahwa buku cerita kura-kura sang juara dilengkapi dengan gambar ilustrasi.

Validasi Data Kualitatif yang dilakukan dalam penelitian ini yaitu (1) Ketekunan/keajegan pengamatan, mengamati kejadian-kejadian atau perilaku, sikap, kegiatan yang sesuai dengan topik penelitian secara cermat dan teliti. Dengan demikian peneliti dapat memperoleh data yang akurat. Sebagai bukti penelitian yang akurat peneliti menggunakan alat bantu seperti kamera Handphone . (2) Triangulasi, peneliti melakukan pemeriksaan kembali dengan cara mengecek ulang data yang sudah peneliti peroleh. Tekniknya dengan mengecek kembali melalui tiga cara, yaitu : Triangulasi sumber, Triangulasi Wawancara lalu dilihat dengan hasil observasi dan dokumentasi harus berkesinambungan. (3) Pengecekan anggota, peneliti melakukan proses pengecekan data yang diperoleh peneliti kepada pemberi data. Hal ini agar informasi yang diperoleh peneliti akan digunakan dalam penulisan laporan sesuai dengan yang dimaksud sumber data atau informan. (4) Kecukupan referensial, peneliti menggunakan alat bantu sebagai pendukung pengumpulan data seperti kamera untuk foto dan merekam suara. Maka hasil foto dan rekaman dapat menggambarkan aktifitas yang terjadi

\section{SIMPULAN DAN SARAN}

Berdasarkan hasil penelitian keterbacaan visual media buku cerita fabel "Kura-Kura Sang Juara" anak usia 5 - 6 tahun di Cluster Rakata Green Hill adalah baik, hasil penelitian menunjukan bahwa buku cerita fabel "Kura-Kura Sang Juara" memilki kosakata yang mudah dipahami serta kesesuaian penyajian kulitas media visual dengan gambar yang disajikan adalah baik. Hal ini telihat dari ketika anak membaca buku cerita fabel "Kura-Kura Sang Juara" dengan baik, anak dapat menjawab pertanyaan mengenai buku cerita fabel "Kura-Kura Sang Juara" serta dapat meceritakan kembali kepada peneliti atau orangtua nya tentang isi dari buku cerita fabel "Kura-Kura Sang Juara".

Berdasarkan kesimpulan hasil penelitian maka saran yang dapat peneliti sampaikan dengan 
harapan dapat dijadikan sebagai masukan yang dapat mengarahkan menjadi lebih baik adalah sebagai berikut: Pertama, bagi orang tua, hendaknya dapat memilih media visual buku cerita yang memiliki kualitas gambar yang baik dan sesuai dengan kosa kata yang disajikan dalam buku tersebut serta dapat membacakan atau menceritakan media buku cerita dengan kreatif sehingga dapat memotivasi anak untuk membaca. Kedua, bagi ilustrator dan penerbit, hendaknya ketika akan mengeluarkan sebuah media buku cerita bergambar agar lebih memperhatikan lagi kualitas dari visual berupa gambar yang lebih nyata dan penulisan kosa kata yang sederhana untuk bisa dipahami anak.

\section{DAFTAR PUSTAKA}

Adipta, H., Maryaeni, M,. \& Hasanah, M. (2016). Pemanfaatan Buku Cerita Bergambar Sebagai Sumber Bacaan Siswa SD. 1(5), 989-992.

Arizpe, E., \& Styles, M. (2015). Children Reading Picturebooks: Interpreting Visual Texts. London: Routledge.

Faizah, U. (2009). Keefektifan Cerita Bergambar Untuk Pendidikan Nilai Dan Keterampilan Berbahasa Dalam Pembelajaran Bahasa Indonesia. 28(3), 249-256.

Mitchell, D. (2003). Children's Literature an Imitation to the Word. Michigan State University.

Moleong, L. J. (2010). Metode Penelitian Kualitatif Edisi Revisi. Jakarta: PT. Remaja Rosda Karya.

Nurgiyantoro, B. (2005). Sastra Siswa dan Pengantar Memahami Dunia Siswa. Yogyakarta: UGM Press.

Pranayama, A. (2006). Teaching Visual Literacy Through Digital Photography And Imaging Exercises. 8(2), 58-64.

Riddle, J. (2009). Engaging The Eye Generation: Visual Literacy Strategis For The K-5 Classroom. USA: Stenhouse Publisher.

Sugiyono, (2014). Metode Penelitian Kuantitatif, Kualitatif, Dan R\&D. Bandung: Alfabeta

Sugiyono. (2010). Metode Penelitian Pendidikan. Bandung: Alfabeta.

Suyanto, S. (2005). Pembelajaran Untuk Siswa TK. Jakarta: Depdiknas. 